\title{
Property Tax Planning based on the Perspective of Real Estate Owner
}

$$
\text { Shuyu Peng }{ }^{1, \text { a }}
$$

${ }^{1}$ Oxbridge College, Kunming University of Science and Technology, Kunming, Yunnan, 650106

a email

\section{Keywords: Estate Owner Perspective, Property Tax, Planning Research}

\begin{abstract}
The real estate industry plays an important role in the development of the national economy. It is also an important source of fiscal revenue and a key area of tax inspection. With the increasing of the whole industry, the real estate development enterprises are very necessary to carry out tax planning. Based on the significance of the tax planning of real estate development enterprises, this paper studies the specific tax planning strategies of real estate development enterprises at different stages, and then summarizes the problems existing in the tax planning of real estate industry in China and puts forward some suggestions: This paper argues that real estate development enterprises should Planning awareness, training tax planning professionals, strengthen tax planning risk management and other aspects to enhance the practical effect of tax planning in the enterprise.
\end{abstract}

\section{Introduction}

With the country to encourage the healthy development of the real estate industry, the government on the real estate macro - control policies emerge in an endless stream of tax as a lever has become one of the direction of real estate regulation. As an important part of enterprise financial management, tax planning has become an effective measure for real estate development enterprises to reduce the tax burden reasonably, realize enterprise efficiency and enhance their own market competitiveness. The so-called tax planning refers to the taxpayers in the complex tax-related environment, in accordance with the premise of compliance with the tax law, through reasonable arrangements and planning business activities to avoid tax risk, control, reduce tax burden to achieve tax Efficiency for the purpose of maximizing economic activity.

Tax planning is an important part of the current financial management of enterprises, reasonable tax is also the obligation and responsibility of enterprises. Therefore, whether the tax awareness is more clear and correct also directly affect the corporate tax planning work is reasonable and effective. It is not only necessary to clarify the importance of property tax tax planning, but also to effectively alleviate the economic pressure on the cost of the enterprise. At the same time, it is necessary to effectively plan and distinguish the illegal tax evasion and tax evasion, Tax planning process into a tax evasion of the legal errors which, thus affecting the healthy development of enterprises.

Want to achieve a positive and effective property tax planning can not be separated from the quality of the fine financial management and planning team. And the current enterprises in the development process blindly expanded, the expansion of the situation is more obvious, in the internal management team building and quality improvement work is insufficient, especially in the financial management and specialized tax planning outstanding performance, so that enterprises in the tax Planning work has been unable to achieve a substantial level of breakthrough. Therefore, enterprises must strengthen the quality of financial management team construction, especially for the specific requirements of the property tax planning special staff to introduce, not only to strengthen the pre-job assessment and qualification, but also on the specific production and operation of enterprises and development characteristics To carry out fruitful pre-job training and the follow-up training and skills during the post to enhance, to strengthen the specialization of real estate tax on the introduction of specialized personnel, while strengthening laws and regulations and other related knowledge of publicity and education, so as to allow enterprises in the premise of rationalization Better to carry out property tax planning work. 


\section{Research on Taxation Measures}

Earnestly study the scope of property taxation. A careful study of the scope of taxation is the prerequisite and basis for achieving reasonable taxation. At present, China's real estate tax scope is mainly in the city, township and township areas at all levels. Therefore, enterprises should first consider whether they are within the scope of collection, and seriously consider the business construction can effectively avoid these levies, such as the production plant, material warehouse, etc., whether to avoid the re-location of these levy area, if Yes, then you can greatly reduce the tax burden on enterprises to reduce the amount of tax taxes on property taxes, of course, in this case we have to seriously avoid the scope of taxation and production plants, warehouses and other buildings will be built in remote places If the cost of the enterprise is higher than the payment of the property tax, then there is no need for another site, so the purpose of taxation is not the same as the cost of the taxpayer. Is to reduce the amount of individual taxes and fees, but to minimize the overall cost of the enterprise expenditure. So in the process of tax planning must stand in the overall height to a comprehensive measure of all aspects of the cost of the problem, to seek the best economic control point.

Self-use housing property tax is based on the original value of the property minus 1 percent to 3 percent after the basis for tax calculation, so the enterprise first to strengthen the original value of self-use housing to maximize the rationalization of the reduction, thereby reducing the tax base. In the self-use housing real estate reduction, the most important point is the need for more detailed sub-accounting, according to the relevant provisions of the property tax levy regulations, independent of the building outside the building does not carry out property tax levy, so enterprises We must be more stringent and meticulous planning their own production and construction, work environment construction, personnel learning environment construction and entertainment and living environment construction and other aspects of the problem, as far as possible will not need to set up with the housing set up a separate construction, but at the same time But also pay attention to the rationality and independence of the construction alone, otherwise the same as an integral part of the house was levied property tax. Strengthen the timely reconciliation of accounts and update the data. Housing as an important business in the production and operation of fixed assets, must be the corresponding financial account registration, and the account data will be used as property tax collection of important data basis, so for these data and information must be updated and entered, because the housing in The use of the process will inevitably bring real estate value of the continuous decline, but if not timely data updates, it is likely to cause the value of the account does not match with the actual value, so that the original value of the property on the account was virtual High, resulting in property tax levy base increase, it is necessary to strengthen the account cleanup and data entry, and regularly to the relevant departments of the property loss of the work, to ensure that the amount of property tax levy the rationality. Self-use housing real estate tax planning should also pay attention to the planning of real estate maintenance, because according to the relevant provisions of the tax law, housing maintenance spending how to reach the original value of more than $50 \%$ of the building and after maintenance can extend the life of the building more than 2 years, The need to increase the basis of fixed assets tax, so companies should pay attention to the dispersion of maintenance, the cost of decentralization and maintenance of the scale as much as possible so that these costs can be directly included in the profit and loss and will not cause the basis of real estate tax Increase, and ultimately reduce the amount of tax on property taxes.

In the rental housing tax research, we must first understand that the tax basis for property tax is the housing rent and it should strengthen the rental of rent accounting work. And the property tax in the housing rent of the provisions also clearly pointed out that the rental tax basis is only the housing rental, and for other services, service fees, equipment rental fees, service supplies, etc. are not included in the tax basis, So the enterprises in the housing rental to be more detailed division of these projects and income projects, the rental housing equipment, supplies and other rental costs listed separately, so that can greatly reduce the calculation of property tax when the basis of the amount, Reduce the total amount of property tax. At the same time for some large-scale, idle real estate more enterprises, the property to the associated enterprises to rent can also reduce the amount 
of property tax paid, because the leasing business does not have the property of property rights, you can in accordance with the provisions of the tax law to avoid property tax Of the payment, thereby reducing the property of all enterprises in the property tax costs.

\section{Change the Way to Achieve Tax Planning}

According to the Provisional Regulations on Real Estate Tax, the property tax is paid by the owner of the property right. Therefore, the enterprise can use the form of sublease to carry out the property tax planning, sublet the property to its related party, it can be an individual or a business, Such as the company shareholders to invest in other companies. Since the sublease of the property is not the owner of the property, it is not necessary to pay the property tax, only to pay business tax and additional. Specific analysis see the following cases: Case: Dahua company has a hotel, its original value of 10 million yuan, 90 million yuan per year rent directly to the external rental. Dahua company rental hotel should pay the property tax $=90 \times 12 \%=10.8$ (million), should pay the business tax and additional $=90 \times 5 \% \times(1+7 \%+3 \%)=4.95,15.75$ (million) If the Dahua company to change the way the hotel rental, the hotel rents 500,000 yuan per year to the subordinate subsidiary, the company will re-lease the hotel, the rent is 900,000 yuan per year. Dahua company should pay the property tax $=50 \times 12 \%=6$ (million), should pay the business tax and additional $=50 \times 5 \% \times(1+7 \%+3 \%)=2.75$ (million), the total 875,000 yuan. The subsidiary is the property sub - tenant, does not pay the property tax, only pay business tax, should pay the business tax and additional $=90 \times 5 \% \times(1+7 \%+3 \%)=4.95$ (million). After the tax planning Dahua company and the subsidiary of the total tax burden $=8.75+4.95=13.7$ (million), can be seen from the rent to sublet, you can save the tax burden of 20,500 yuan. However, it should be noted that the above tax planning to meet the property sublease to pay more business tax and additional property is greater than the lessor of the property tax, so that the tax planning program is feasible. In other words, if the owner of the property transferred to the property of the rent, sub-tenant rent again rent $\mathrm{B}$, as long as the satisfaction $(\mathrm{B}-\mathrm{A}) 12 \%-\mathrm{B} \times 5.5 \%$ greater than 0 , planning program feasible.

Enterprises can change the way for the consignment for the way to achieve effective tax planning, to achieve the purpose of tax savings, the following through a case to illustrate. Case: A company will be a small shopping mall to B company for its sales of production for products, the annual rent of 1 million yuan, the property tax value of 10 million yuan. Company A and Company B are VAT general taxpayers. A company to obtain the rental income should pay the relevant tax as follows (assuming only consider the business tax and property tax): A company should pay a business tax each year: $100 \times 5 \%=50,000$ yuan, A company should pay the property tax each year: $100 \times 12 \%$ $=12$ million. If $\mathrm{A}$ company to use the small shopping malls for the $\mathrm{B}$ company consignment products, consignment of product varieties, the price can be determined by the B company, A company only charge consignment fees. Assuming that A company's annual collection fee is still 100 million yuan, A company should bear the relevant tax: the annual business tax payable: $100 \times$ $5 \%=50,000$ yuan, the annual property tax payable: $1000 \times(1-30 \%) \times 1.2 \%=8.4$ million, we can see that after the planning of E companies can bear the property tax 12-8.4 = 3.6 million.

\section{Conclusion}

Property tax is an important part of China's tax system, which not only can enhance the level of modern development of enterprises, but also can promote the continuous progress of China's tax reform, but the tax will always bring more economic burden and cost increase, Therefore, to strengthen the rationalization of property tax planning has become an important part of enterprise financial management work, property tax planning is a professional and normative system engineering, only from the consciousness, personnel, specific measures to strengthen the work of many aspects, Can effectively help enterprises to better achieve tax planning, and maximize the collection of taxes and fees concessions to promote the healthy development of enterprises. 


\section{References}

[1] Zeng Qi. Analysis of real estate enterprises tax planning risk prevention measures [J]. Modern economic information, 2014 (01)

[2] Li Yao. Real estate enterprises tax planning risk prevention measures [J]. Times Finance, 2015 (29)

[3] Meng Qi. New situation under the real estate business tax planning thinking [J]. China's collective economy, 2012 (30)

[4] Qu Jing. Real estate business tax planning some thoughts [J]. Today's wealth, 2016 (10)

[5] Liu Gangshan. Real estate development enterprise tax planning [J]. New Economy, 2015 (26)

[6] Zhang Yi. Analysis of real estate enterprises in the tax planning problems and countermeasures [J]. Enterprise Herald, 2015 (24) 